\title{
IMPACTS OF BAMBUSA BAMBOS SPREAD ON SEEDLING RECRUITMENT, MORTALITY AND REGENERATION POTENTIAL OF NATIVE SPEGIES IN TROPICAL MOIST EVERGREEN FORESTS OF SRI LANKA
}

\author{
Wijewickrama $\mathbf{T}^{1,4, *}$, Karunaratne $\mathbf{I}^{2}$, Wijesundara $\mathbf{S}^{3} \&$ Madawala $\mathbf{S}^{4}$ \\ ${ }^{1}$ Postgraduate Institute of Science, Peradeniya, 20400 Sri Lanka \\ ${ }^{2}$ Department of Zoology, Faculty of Science, University of Peradeniya, Peradeniya, 20400 Sri Lanka \\ ${ }^{3}$ National Institute of Fundamental Studies, Hantana Road, Kandy, 20000 Sri Lanka \\ ${ }^{4}$ Department of Botany, Faculty of Science, University of Peradeniya, Peradeniya, 20400 Sri Lanka \\ *tharanga985@gmail.com
}

Submitted November 2020; accepted March 2021

\begin{abstract}
Some native plants expand their populations rapidly in their home ranges, altering their structure and composition. Bambusa bambos, a native bamboo species, shows a rapid population expansion in tropical moist evergreen forests in the intermediate climatic zone, Sri Lanka. The present study was conducted to evaluate its impacts on the regeneration potential of other native forest species. The seedling emergence, survival and mortality were observed for a period of one year using quadrats laid along 18 transects marked from the forest edge towards the forest interior in forest patches with and without bamboo $(+\mathrm{Bb}$ and $-\mathrm{Bb}$, respectively). The results revealed a higher abundance, richness and diversity of seedlings in $+\mathrm{Bb}$ than in - $\mathrm{Bb}$, with lianas and herbs contributing more to these differences. However, tree seedlings showed higher turnover rates (recruitment and mortality) in -Bb, indicating their preference for undisturbed habitats. Tree and shrub seedlings survived better in -Bb forests while liana and herbaceous seedlings displaying the opposite. The results indicate that B. bambos spread showed an ability to alter the regeneration potential of native forests probably resulting bamboo-driven changes to micro-environmental conditions in the forest floor.
\end{abstract}

Keywords: Bambusa bambos, tropical moist evergreen forests, Sri Lanka, regeneration potential, mortality, survival

\section{INTRODUCTION}

The tropical dry forests are one of the most vulnerable and relatively less-studied ecosystems in the world (Murphy \& Lugo 1986). At present they are under threat due to many natural and anthropogenic factors, thus needing more attention in research. Once disturbed, the recovery process of these forests is greatly hindered due to the lack of tree seedling emergence and their survival, as the survival is highly constrained by lack of water, nutrients, shade and grass competition (Vadigi \& Ward 2013, Bhadouria et al. 2016).

In the global context, the native forest cover is in decline over time, while the bamboo-dominated forests are expanding their territories in the tropics, raising concerns among ecologists and conservationists (Benzhi et al. 2005). Bamboos are an important component of tropical, sub-tropical and temperate forest ecosystems, with some species showing abilities to expand populations in a rather ad-hoc manner possibly driven by natural and anthropogenic disturbances and/or climate change (Larpkern et al. 2011, Lima et al. 2012). These native bamboo species form monospecific stands due to recurring disturbances such as fire, windstorms etc., threatening the quality of their resident communities (Gagnon \& Platt 2008, Kercher \& Zedler 2004). However, some of these species cannot be categorised as invasive due to their native status. This could be another reason for the lack of attention from scientists assessing their immediate impacts on their native ranges despite their behavioral similarities with that of exotic invasive species.

Once the dominance hierarchy is altered in plant communities, significant modifications to the forest structure and composition could be expected, if the dominant species differs greatly in terms of structural and physiological features 
from the preceding species (Larpkern et al. 2011). Therefore, the rapid spread of bamboos not only affects the structure and composition of forests, but also their functions (Griscom \& Ashton 2003, Fantini \& Guries 2007, Rother et al. 2009, Larpkern et al. 2011, Lima et al. 2012, Rother et al. 2013). Studies also noted that bamboos hinder the regeneration potential of tree species through their competitive supremacy in terms of their ability to capture light, and absorb nutrients and water (Abe et al. 2002, Narukawa \& Yamamoto 2002, Griscom \& Ashton 2003, Guilherme et al. 2004, Taylor et al. 2004, 2006). Hence, the evaluation of bamboo-driven impacts on the regeneration process of native forests needs attention from the researchers to predict present status and future trends, and also to find ways to minimise their undesirable impacts, if any.

The evaluation of regeneration potential of forests provides not only the present status of the vegetation, but also to predict imminent changes in the composition and structure of the forest (Malik \& Bhatt 2016). The growth and survival of seedlings are largely regulated by resources (light, water and nutrients) and disturbances (fire, competition, defoliation etc.), thus the bamboo spread could also, alter the regeneration potential through its unusual life traits and competitive ability over co-existing species (Abe et al. 2002, Griscom \& Ashton 2003, Wang et al. 2012). Bamboos are known to inflict changes in forest dynamics through their high production of litter following synchronised flowering and dying cycles (Santos \& Valio 2002, Zhou et al. 2005, Araujo 2008, Larpkern et al. 2011). The high input of less compostable litter together with other impacts on altering the forest structure (through their ability of increasing tree mortality) could modify the microclimate in the forest floor, thus affecting the germination, establishment and survival of seedlings (Facelli \& Picket 1991, Liu et al. 2000, Zhou et al. 2005, Wijewickrama et al. 2020). In addition, high light intensity and drought are also considered as decisive factors for seedling establishment and survival in the tropics (Tanaka 1988, Gerhardt 1996). Studies noted that bamboos impose negative influences on the regeneration potential, where pioneer species tend to compete with other native species for sunlight in forest gaps that are more frequent in bamboo forests (Tabarelli \& Mantovani 2000,
Felker et al. 2017). In favour, Taylor et al. (2006) noted a negative relationship between density of bamboo and the abundance of tree seedlings in a study carried out in a native forests in south west of China.

Bambusa bambos is a native bamboo species common to south and south-east Asian countries including Sri Lanka (Yeasmin et al. 2015). The B. bambos is expanding its populations in forests, in both dry and intermediate climatic zones of the island causing structural and compositional changes of forest communities (Wijewickrama et al. 2020). Despite its highly patchy spread in these native forests, no comprehensive studies have been undertaken so far in Sri Lanka to evaluate its potential impacts on forest communities. Therefore, the current study was carried out to explore the $B$. bambos driven impacts on the regeneration potential in a tropical moist evergreen forest in the intermediate climatic zone of Sri Lanka. Thus, it was hypothesised that $B$. bambos negatively impact the regeneration potential of these forests, modifying the forest composition and structure.

\section{MATERIALS AND METHODS}

\section{Study area}

The study was conducted from March 2017 to February 2018 in Moragahakanda area $\left(7^{\circ} 41^{\prime} \mathrm{N}, 80^{\circ} 42^{\prime} \mathrm{E}\right)$ which is located in the intermediate climatic zone in the Central Province of Sri Lanka. The topography of the area is classified as flat to gentle slopes, while the landscape in the region is shaped by the Knuckles Mountain Range (IUCN 2007). The geology of the area is of Highland Series from the pre Cambrian era. Reddish brown earths and immature brown loams are the major soil types along with erosional remnants (Somasekaram 1988). The mean annual temperature ranges from $22.5-25.0^{\circ} \mathrm{C}$ and the mean annual rainfall varies from $2,000-2,500 \mathrm{~mm}$. The study area receives a significant portion of its annual rainfall from the north-east monsoons from December to February, with a long dry spell from May to September. Since the study site is located in the north-eastern foothills of the Knuckles Mountain Range, the area receives little precipitation from the south-western monsoon (May to September) due to the shielding effect. 
Tropical moist evergreen forests (TMEFs) are the dominant native forest type in the study area. As these forests are located in the transition zone between seasonal and aseasonal climates, they usually comprise of species belonging to both tropical lowland wet evergreen forests and tropical dry mixed evergreen forests (Gunatilleke et al. 2008). The TMEFs are characteristic of high abundance of lianas, with three clearly identified strata including a canopy (20-25 m), a sub-canopy/shrub layer (5-10 m) and ground vegetation. The mature forests have a continuous canopy with a sparse ground vegetation. The study area has been extensively modified in recent past due to the construction of a mega hydropower project MoragahakandaKalu Ganga Development Project (2007 to 2018). A large extent of forests has been cleared or disturbed in order to build dams, two major reservoirs (Moragahakanda and Kaluganga) and new townships for displaced people. Other landuse types in the area include scrub jungles, riverine forests, rock-out crops, agricultural lands and home gardens.

Bambusa bambos prefer a humid tropical climate with a low to moderate elevation $(<$ than $1,000 \mathrm{~m}$ ) and a rainfall of 2,000-2,500 $\mathrm{mm}$, and as a result its distribution has stretched from the intermediate climatic zone to the immediate margins of the dry zone (Sarojam $\&$ Kumar 2001). Over the past few decades, $B$. bambos populations have expanded in a rather rapid and patchy manner in TMEFs causing both ecological and social consequences (Wijewickrama et al. 2019, 2020). However, the causal factors of this rapid expansion of $B$. bambos is still unknown.

\section{Study sites}

The study was conducted in selected forest patches with high prevalence of bamboo (with bamboo cover more than $50 \%,+\mathrm{Bb}$ ) from three different localities in close proximity (approximately $2-6 \mathrm{~km}$ apart from each other) (Figure 1). For comparison, three forest patches without bamboo (-Bb) were also selected from respective localities. In - Bb forests, a few occasional bamboo bushes were noted. The stature (10-15 and 8-20 m) and the stem densities $(3,404$ and 3,352 per ha) were differed between bamboo $(+\mathrm{Bb})$ and non-bamboo (-Bb) forest communities, respectively.

\section{Enumeration of seedling communities}

In each bamboo- or non-bamboo forest patches, three $110 \mathrm{~m}$ parallel transects $(\sim 20$ $\mathrm{m}$ apart) were laid from the edge of the forest towards the forest interior, totaling 18 transects ( 3 transects $\times 3$ sites $\times 2$ forest types, $+\mathrm{Bb} /-\mathrm{Bb}$ ). All forest patches are bordered either by a derelict tarred road (leading to a small hamlet),

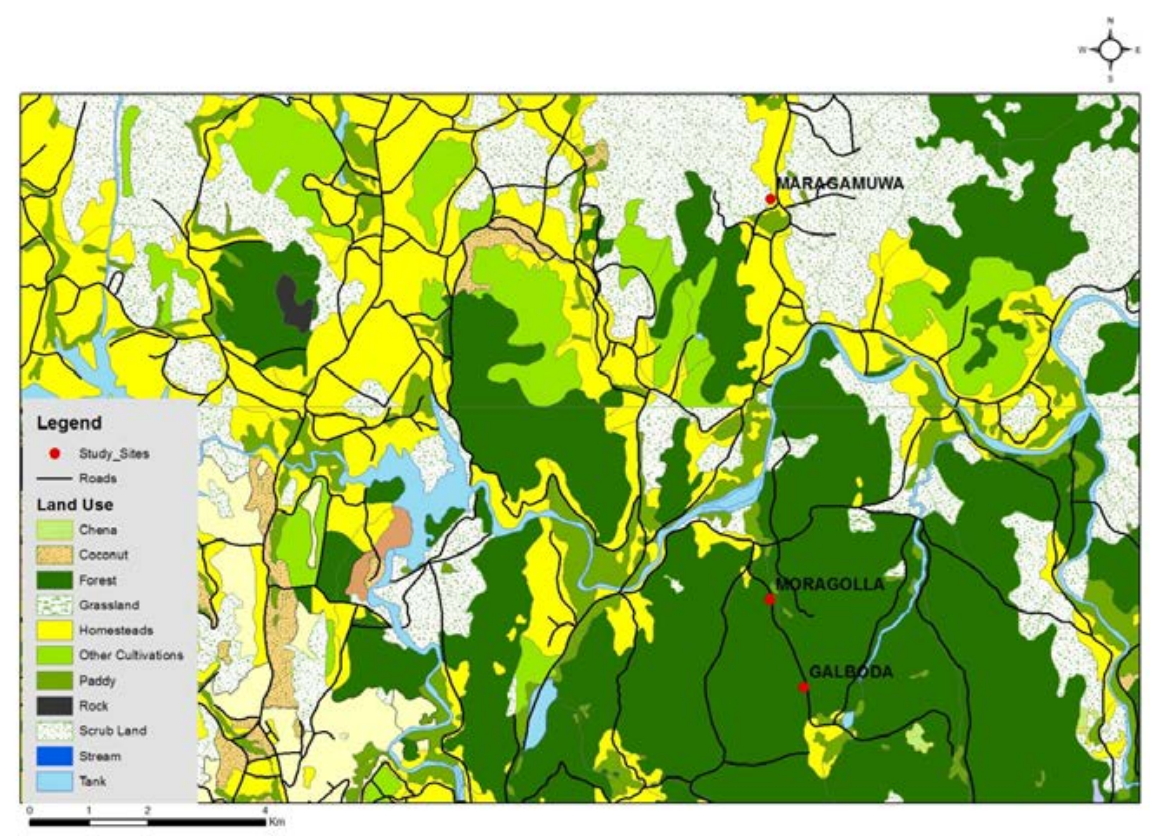

Figure 1 A land use map showing locations of the three study sites, Galboda, Moragolla and Maragomuwa at Moragahakanda area in the Central Province of Sri Lanka 
home gardens or a transmission line corridor. Along each transect, six $10 \mathrm{~m} \times 10 \mathrm{~m}$ quadrats were marked at $0,20,40,60,80$ and $100 \mathrm{~m}$ from the forest edge towards the forest interior to enumerate the vegetation (Wijewickrama et al. 2020). To enumerate seedlings, one $1 \mathrm{~m} \times$ $1 \mathrm{~m}$ sub-quadrat was randomly set up in each $100 \mathrm{~m}^{2}$ quadrat, totaling 108 sub-quadrats in both $+\mathrm{Bb}$ and $-\mathrm{Bb}$ forests. All seedlings less than $50 \mathrm{~cm}$ in height were tagged. All seedlings were numbered and identified to their species level wherever possible. New recruits (newly emerged seedlings), survival (remaining seedlings + newly emerged seedling) and dead seedlings were recorded monthly for a period of one year starting from March 2017. For herbaceous plants, only individuals that did not flower or fruit during the study period were included, considering their relatively short life cycle in comparison to other life forms.

\section{Quantification of surface litter biomass}

The surface litter samples were collected using $1 \mathrm{~m}^{2}$ randomly placed wooden frames (outside the $1 \mathrm{~m}^{2}$ permanent quadrats established for enumerate seedlings) within each $100 \mathrm{~m}^{2}$ main quadrat, totaling 108 litter samples from $+\mathrm{Bb}$ and $-\mathrm{Bb}$ forest types. The litter was collected once in three months for a period of one year. The litter samples were cleaned, air dried and weighed using a digital electronic balance.

\section{Data analysis}

The cumulative abundance and species richness of seedlings belonging to four different life forms i.e. trees, shrubs, lianas and herbs were calculated by pooling data collected during the period of one year.
Newly emerged seedlings were recorded (tagged) monthly as recruits while the survival of seedlings (remaining + newly emerged seedlings) were also noted on a monthly basis. The dead individuals were depicted as mortality. The surface litter biomass ( $\mathrm{g}$ per sq. $\mathrm{m})$, recruitment of seedlings and seedling mortality (per sq. m month ${ }^{-1}$ ) were compared between $+\mathrm{Bb}$ and $-\mathrm{Bb}$ forest communities using repeated-measures ANOVA in Minitab (Minitab 2010, Version 17.0). Simpson, Shannon, Evenness, Menhinick and Jaccard indices were calculated using Past statistical software (Past 3.26). Species accumulation curves were generated by using Past (Past 3.26) statistical software and Microsoft Excel 2007.

\section{RESULTS}

\section{Seedling abundance and diversity}

A total of 4,005 seedlings belonging to 154 morphotypes were recorded in the study. Nearly $86 \%$ of the morphotypes were identified to their species, genus or family levels (Appendix). The total abundance of seedlings was higher in $+\mathrm{Bb}$ forests than in $-\mathrm{Bb}$, with a marked contribution from herbs and lianas in the latter forest type. The tree seedlings were more abundant in -Bb forests than in $+\mathrm{Bb}$, though no difference in richness was noted between the two stands (Table 1). The exclusive species were relatively higher in $+\mathrm{Bb}$ forests (60) than in $-\mathrm{Bb}$ (17) with 59 species were common to both forest types $(\approx$ $44 \%$ ). Diversity indices and evenness (Pielou, $\mathrm{J})$ values were higher in $+\mathrm{Bb}$ forests than that of non-bamboo (-Bb) stands (Table 1 ).

The Jaccard index (44.4\%) suggests

Table 1 Abundance and richness of seedling communities in bamboo $(+\mathrm{Bb})$ and non-bamboo (-Bb) stands in sites at Moragahakanda area, Central Province, Sri Lanka

\begin{tabular}{lccccc}
\hline & \multicolumn{2}{c}{ Cumulative abundance } & & \multicolumn{2}{c}{ Cumulative richness } \\
\cline { 2 - 3 } \cline { 5 - 6 } & $+\mathrm{Bb}$ & $-\mathrm{Bb}$ & 702 & $+\mathrm{Bb}$ & $-\mathrm{Bb}$ \\
\hline Trees & 554 & 363 & 90 & 35 & 35 \\
Shrubs & 483 & 533 & 19 & 23 & 14 \\
Herbs & 515 & 1688 & 30 & 6 \\
Liana & 765 & 2317 & & 119 & 76 \\
Total & & & & 30 \\
\hline
\end{tabular}


a low similarity of seedling communities between bamboo and non-bamboo forests. In non-bamboo forests, the species accumulation curve (all seedlings) reached the plateau quicker than that of bamboo forests. However, the species accumulation rate of herbaceous species was higher in bamboo forests than that of non-bamboo forests (Figure 2).

Table 2 Diversity index (Shannon, H') and evenness (Pielou, J) of seedling communities in bamboo $(+\mathrm{Bb})$ and non-bamboo $(-\mathrm{Bb})$ stands in sites at Moragahakanda area, Central Province, Sri Lanka

\begin{tabular}{|c|c|c|c|c|c|c|}
\hline & & Simpson & Shannon & Evenness & Menhinick & Jaccard Index \\
\hline \multirow{2}{*}{ Trees } & $+\mathrm{Bb}$ & 0.91 & 2.75 & 0.45 & 0.94 & \multirow{2}{*}{54.35} \\
\hline & $-\mathrm{Bb}$ & 0.89 & 2.64 & 0.41 & 0.78 & \\
\hline \multirow{2}{*}{ Shrubs } & $+\mathrm{Bb}$ & 0.88 & 2.44 & 0.6 & 0.76 & \multirow{2}{*}{40} \\
\hline & $-\mathrm{Bb}$ & 0.75 & 1.75 & 0.41 & 0.56 & \\
\hline \multirow{2}{*}{ Lianas } & $+\mathrm{Bb}$ & 0.86 & 2.41 & 0.37 & 0.73 & \multirow{2}{*}{44.11} \\
\hline & $-\mathrm{Bb}$ & 0.63 & 0.21 & 0.21 & 0.5 & \\
\hline \multirow{2}{*}{ Herbs } & $+\mathrm{Bb}$ & 0.87 & 2.27 & 0.42 & 0.69 & \multirow{2}{*}{24} \\
\hline & $-\mathrm{Bb}$ & 0.48 & 0.97 & 0.44 & 0.42 & \\
\hline \multirow{2}{*}{ Overall } & $+\mathrm{Bb}$ & 0.97 & 3.89 & 0.41 & 1.7 & \multirow{2}{*}{44.36} \\
\hline & $-\mathrm{Bb}$ & 0.93 & 3.2 & 0.32 & 1.15 & \\
\hline
\end{tabular}
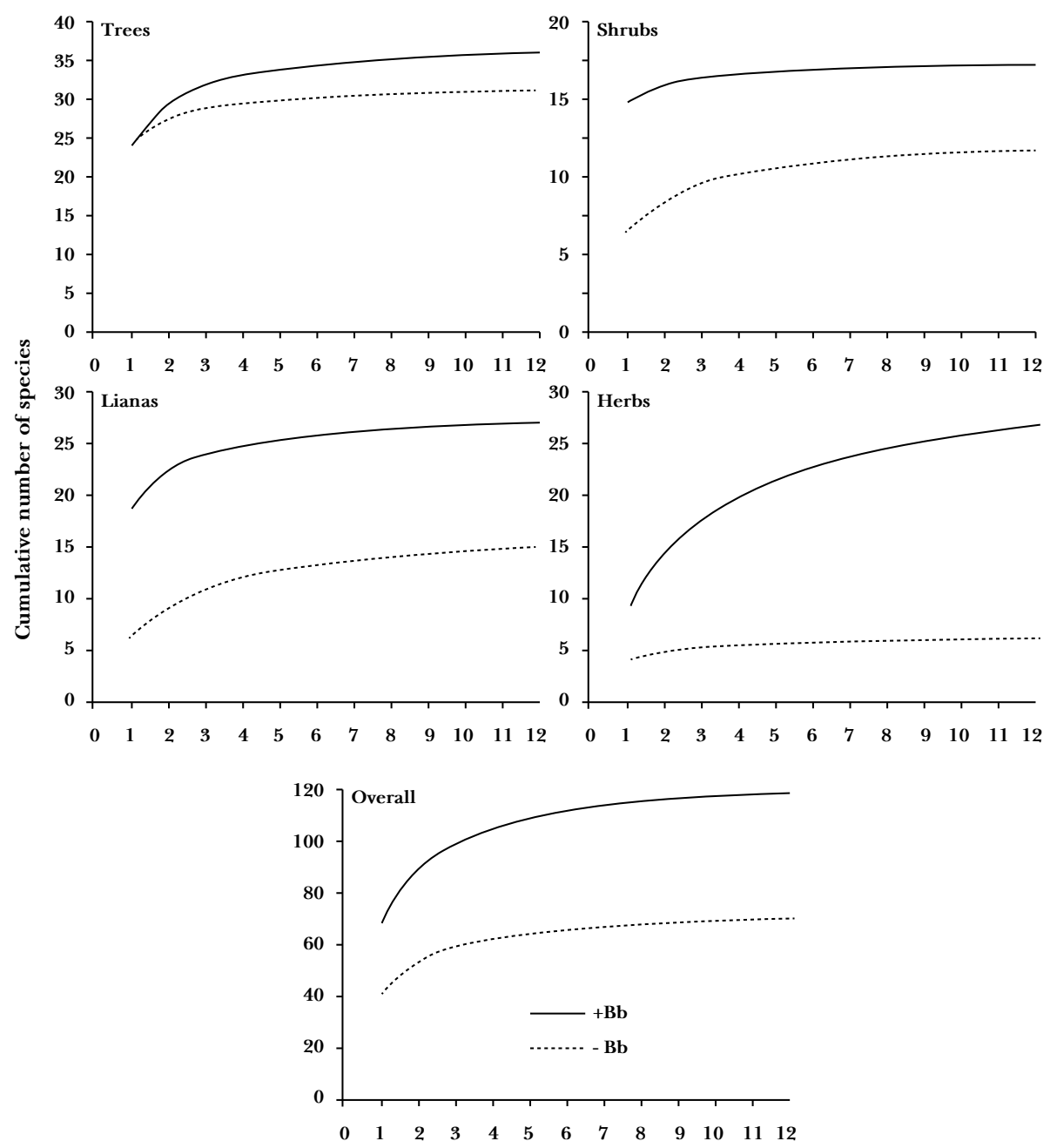

Figure 2 Species accumulation curves of seedlings in different life forms and overall for bamboo- (solid line) and non-bamboo (dotted line) forests at Moragahakanda in the Central Province, Sri Lanka 


\section{Seedling recruitment, survival and mortality}

The overall mortality of seedlings was significantly higher in $+\mathrm{Bb}$ than that of $-\mathrm{Bb}$. Though the overall seedling recruitment and survival showed no significant differences between bamboo and non-bamboo forests, interesting disparities were noted between forest communities in terms of different life forms. The recruitment and survival of tree seedlings were consistently higher in $-\mathrm{Bb}$ forests than in $+\mathrm{Bb}$, while the opposite was noted with herbaceous seedlings. The liana seedlings were better survived in $+\mathrm{Bb}$, though there were no differences in recruitment and mortality between forest stands (Table 3 ).

The $-\mathrm{Bb}$ forests showed a significantly higher accumulation of surface litter biomass compared to $+\mathrm{Bb}$ forests (Table 3), and this increase was more marked during the drier months.

\section{Seasonal variations of seedling recruitment, survival and mortality}

The overall seedling recruitment, survival and mortality have demonstrated high seasonality with no distinct trends among the two forest communities, $+\mathrm{Bb}$ and $-\mathrm{Bb}$ (Figure 3). In particular, the seedling recruitment and survival displayed noticeable seasonal fluctuations, with the lowest observed in drier months (April to August) and the highest in wetter months (September to March), irrespective of the presence/absence of bamboo. The seedling mortality also showed no marked differences between $+\mathrm{Bb}$ and $-\mathrm{Bb}$ forest patches, with no special inclinations to wet and dry months.

Of all life forms, tree seedlings were survived better year-round in non-bamboo forests while liana and herbaceous seedlings survived well under the bamboo canopy (Figure 4).

Table 3 Mean seedling density, recruits, mortality and surface litter biomass of bamboo (+Bb) and non-bamboo (-Bb) forests Moragahakanda area, Central Province, Sri Lanka

\begin{tabular}{llll}
\hline & $+\mathrm{Bb}$ & $-\mathrm{Bb}$ & P values \\
\hline Overall mean recruits (per sq. m month ${ }^{-1}$ ) & 2.9 & 2.6 & $0.091^{\mathrm{ns}}$ \\
Overall mean survival (per sq. m month ${ }^{-1}$ ) & 7.0 & 6.7 & $0.432^{\mathrm{ns}}$ \\
Overall mean mortality (per sq. m month ${ }^{-1}$ ) & $2.2^{\mathrm{a}}$ & $1.8^{\mathrm{b}}$ & $0.008^{* *}$ \\
Mean surface Litter (kg per sq. m) & $0.540^{\mathrm{b}}$ & $0.750^{\mathrm{a}}$ & $<0.000^{* * * *}$ \\
\hline Mean seedling recruitment (per sq. m month ${ }^{-1}$ ) & & & \\
\hline Trees & $0.863^{\mathrm{b}}$ & $1.08^{\mathrm{a}}$ & $0.048^{*}$ \\
Shrubs & 0.571 & 0.560 & $0.138^{\mathrm{ns}}$ \\
Liana & 0.894 & 0.823 & $0.441^{\mathrm{ns}}$ \\
Herbs & $0.811^{\mathrm{a}}$ & $0.139^{\mathrm{b}}$ & $0.000^{* * *}$ \\
\hline Mean seedling survival (per sq. m month ${ }^{-1}$ ) & & & \\
\hline Trees & $2.023^{\mathrm{b}}$ & $2.968^{\mathrm{a}}$ & $0.000^{* * *}$ \\
Shrubs & 1.069 & 1.275 & $0.077^{\mathrm{ns}}$ \\
Liana & $2.647^{\mathrm{a}}$ & $2.140^{\mathrm{b}}$ & $0.001^{* * *}$ \\
Herbs & $1.715^{\mathrm{a}}$ & $0.323^{\mathrm{b}}$ & $0.001^{* * *}$ \\
\hline Mean seedling Mortality (per sq. m month ${ }^{-1}$ ) & & & \\
\hline Trees & $0.610^{\mathrm{b}}$ & $0.776^{\mathrm{a}}$ & $0.044^{*}$ \\
Shrubs & 0.495 & 0.397 & $0.890^{\mathrm{ns}}$ \\
Liana & 0.894 & 0.822 & $0.256^{\mathrm{ns}}$ \\
Herbs & $0.627^{\mathrm{a}}$ & $0.097^{\mathrm{b}}$ & $0.000^{* * *}$ \\
\hline
\end{tabular}

$* \mathrm{p} \leq 0.05, * * \mathrm{p} \leq 0.01, * * * \mathrm{p} \leq 0.001,{ }^{\mathrm{ns}}=$ not significant, $\mathrm{a}$ and $\mathrm{b}=$ significant differences 

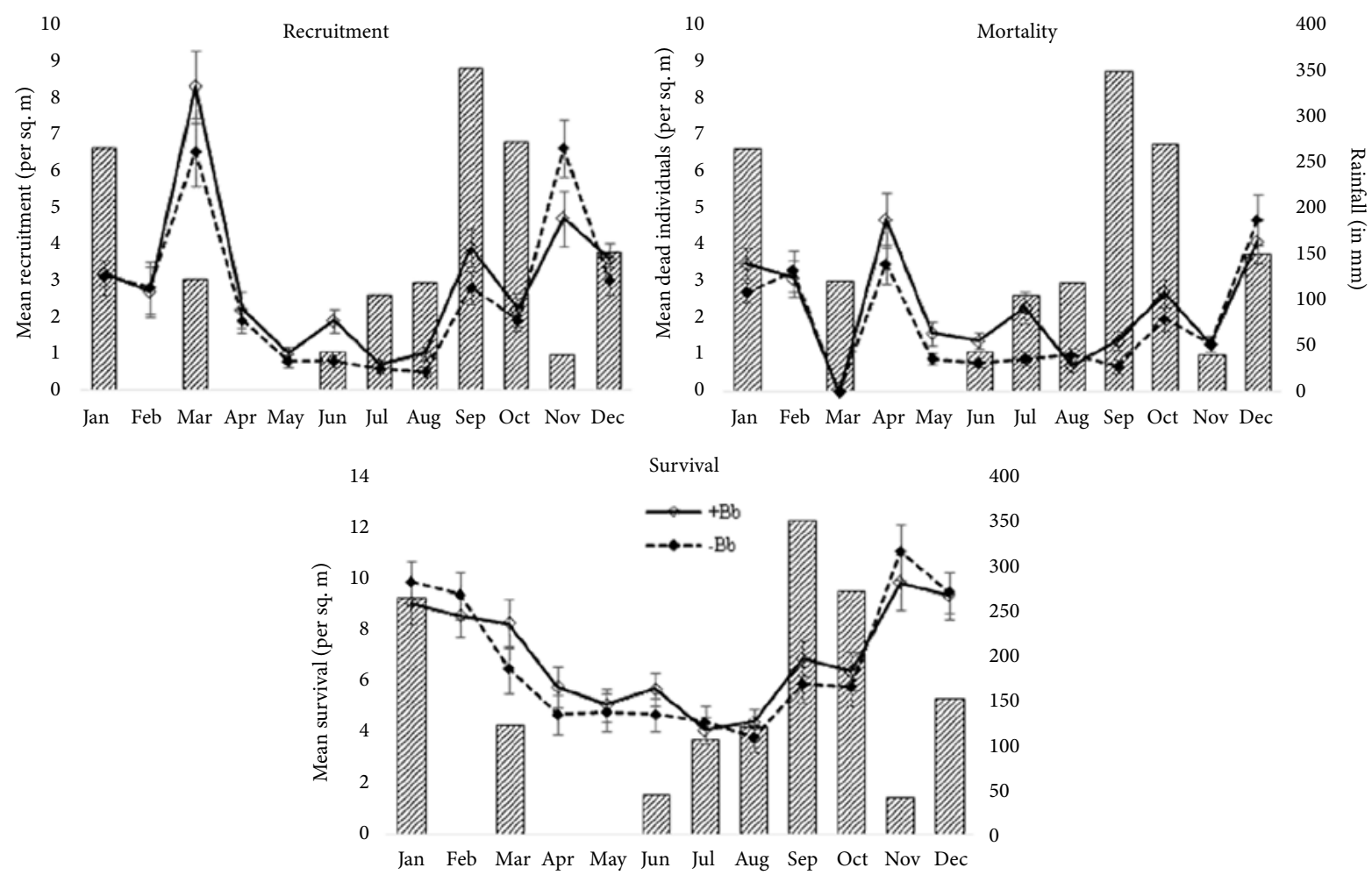

Figure 3 Overall mean recruitments, mortality and survival (per sq. m) from March 2017 to February 2018 in bamboo $(+\mathrm{Bb})$ and non-bamboo $(-\mathrm{Bb})$ forest patches in Moragahakanda area in the Central Province of Sri Lanka; columns filled with upward diagonal lines indicate monthly rainfall $(\mathrm{mm})$ during the study period in March 2017 to February 2018; vertical bars represent standard error of the mean
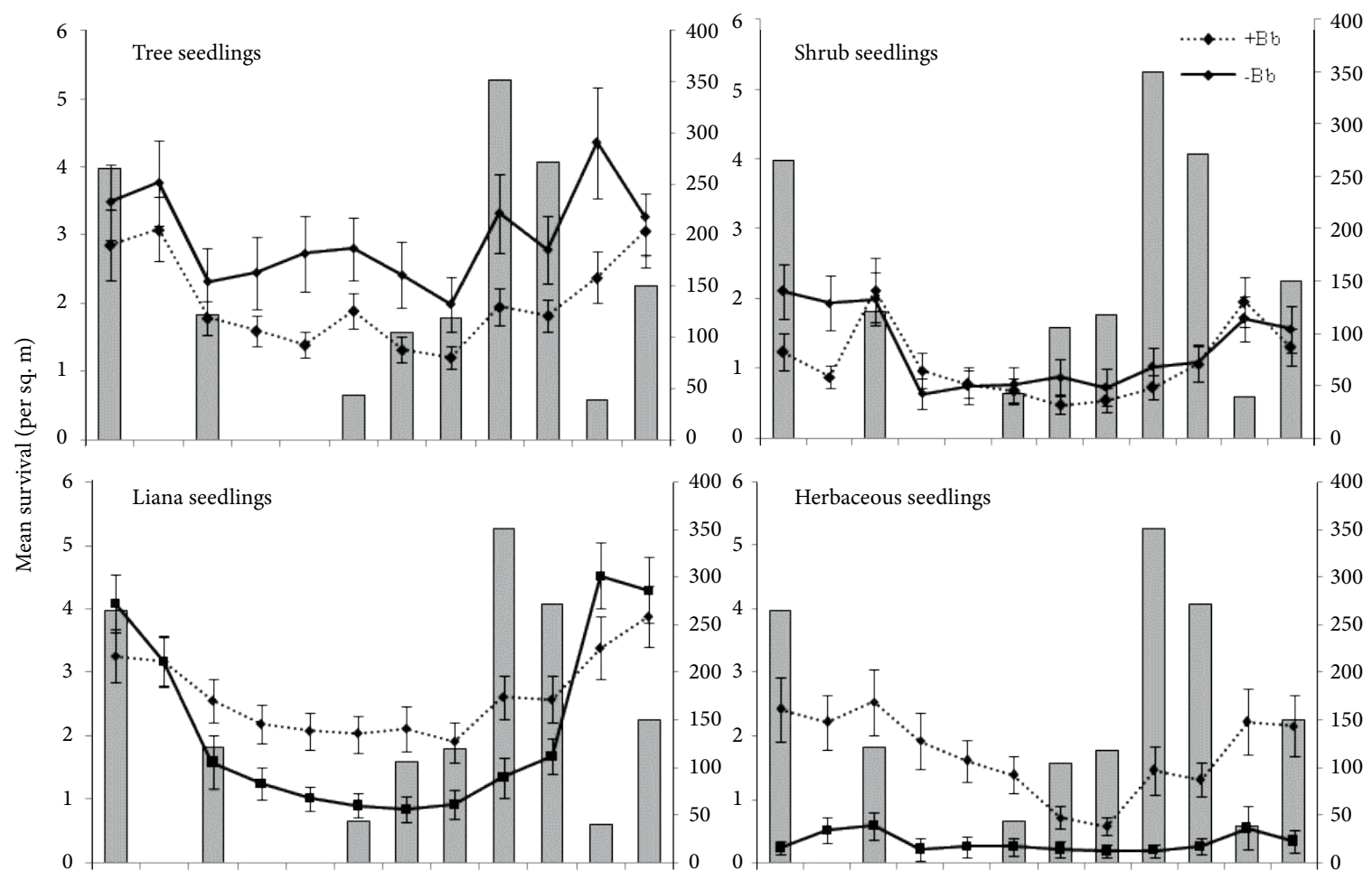

Jan Feb Mar Apr May Jun Jul Aug Sep Oct Nov Dec

Jan Feb Mar Apr May Jun Jul Aug Sep Oct Nov Dec

Figure 4 Mean survival $\left(\mathrm{m}^{-2}\right)$ of tree, shrub, liana and herbaceous seedlings from March 2017 to February 2018 in bamboo $(+\mathrm{Bb})$ and non-bamboo $(-\mathrm{Bb})$ forest patches in Moragahakanda area in the Central Province of Sri Lanka; columns indicate monthly rainfall $(\mathrm{mm})$ during the study period in March 2017 to February 2018; vertical bars represent standard error of the mean 
The seedlings of Dimocarpus longan, a late successional species, showed significantly a higher survival in $-\mathrm{Bb}$, while $P$. suberifolium survived better in $+\mathrm{Bb}$ forests (Table 4 ).

\section{DISGUSSION}

The results suggested that the overall seedling community was more abundant, rich and diverse in $+\mathrm{Bb}$ in comparison to $-\mathrm{Bb}$. More exclusive species recorded in $+\mathrm{Bb}$ forests $(\approx$ $39 \%$ ) highlights the compositional differences between seedling communities of the two forest stands. Though total seedling abundance was higher under the bamboo canopy, seedlings of different life forms (trees, shrubs, herbs and lianas) showed varying preferences for their establishment and survival. Tree seedlings seem to prefer micro-environmental conditions that prevail in non-bamboo forests, while shrub, herb and liana seedlings showed the opposite. The results suggested that the $B$. bambos spread has provided favourable micro-environmental conditions for the establishment of more sunloving seedlings that are common in open areas while non-bamboo forests provide undisturbed conditions for shade-loving plants that are more prevalent in the closed canopy forests. Tree and shrub seedlings are considered as the most important life forms in forest regeneration (Campanello et al. 2007, Caccia et al. 2009). The higher abundance of tree seedlings in non-bamboo forests indicates their preference of undisturbed habitats for establishment and survival. Previous studies demonstrated that bamboos alter the regeneration potential in tropical forests through altering the micro-environment, seed rain and increased accumulation of leaf litter (Araujo 2008, Grombone-Guaratini et al. 2014, Muler et al. 2014, Rother et al. 2016). The micro-environmental conditions in the forest floor seem altered by the bamboo thickets as they disturb the forest canopy, allowing more sunlight to reach the forest floor aiding seed germination and seedling establishment (Guilherme et al. 2004, Fantini \& Guries 2007, Wijewickarama et al. 2020). Despite light being considered as a key limiting factor for the establishment of seedlings, light could also trigger seedling mortality due to greater luminosity (Coomes \& Grubb 2000, Lima et al. 2012, Rother et al. 2016). The reduced densities of tree seedlings and saplings under the bamboo canopy may have been attributed to high light levels (Tanaka 1988, Taylor \& Zisheng 1988, Taylor et al. 2006). High dieback of mature trees together with the dispersed nature of $B$. bambos provide conditions suited for light-demanding pioneer species as well as herbs and lianas. Lianas are known to thrive under disturbed conditions, and they too showed the potential to alter the forest structure over time by slowing down the growth and survival of tree seedlings (Schnitzer et al. 2000, Paul et al. 2004, Campanello et al. 2007, Farah et al. 2014. In a study carried out in Brazil, Rother et al. (2009) observed a higher seedling emergence under the native bamboo canopy of Guadua tagoara, while

Table 4 Survival and mortality (mean per sq. m) of Dimocarpus longon and Pterospermum suberifolium in bamboo $(+\mathrm{Bb})$ and non-bamboo $(-\mathrm{Bb})$ forest communities at Moragahakanda area, Central Province, Sri Lanka

\begin{tabular}{|c|c|c|c|}
\hline & $+\mathrm{Bb}$ & $-\mathrm{Bb}$ & p-value \\
\hline \multicolumn{4}{|l|}{ Dimocarpus longan } \\
\hline Mean survival (per sq. m month (1) $^{-1}$ & $0.137^{\mathrm{b}}$ & $0.765^{\mathrm{a}}$ & $<0.000 * * *$ \\
\hline Mean mortality (per sq. m month ${ }^{-1}$ ) & $0.039^{\mathrm{b}}$ & $0.094^{\mathrm{a}}$ & $0.005^{* *}$ \\
\hline \multicolumn{4}{|l|}{ Pterospermum suberifolium } \\
\hline Mean survival (per sq. m month ${ }^{-1}$ ) & $0.204^{\mathrm{a}}$ & $0.039^{\mathrm{b}}$ & $<0.000^{* * *}$ \\
\hline Mean mortality (per sq. m month ${ }^{-1}$ ) & $0.022^{\mathrm{a}}$ & $0.008^{\mathrm{b}}$ & $0.048 *$ \\
\hline
\end{tabular}

One way ANOVA: * $\mathrm{p} \leq 0.05 ; * * \mathrm{p} \leq 0.01, * * * \mathrm{p} \leq 0.001$ and ${ }^{\mathrm{ns}}=$ not Significant; NA $=$ not analysed; Dimocarpus longan is one of the most dominant tree species in TMEFs of the area, while Pterospermum suberifolium is an early successional species in the same forest type, a and $\mathrm{b}=$ significant differences 
Larpkern et al. (2011) observed the opposite, demonstrating a lack of generalisation of bamboo-driven impacts.

The present results indicate a disparity in seedling communities in $+\mathrm{Bb}$ and $-\mathrm{Bb}$ forest stands, possibly due to their preferences for specific micro-environmental conditions for establishment and survival. Previous studies too confirmed that the composition of seedling communities depend largely on their species-specific requirements and their abilities to withstand varying stress conditions including light (Caccia et al. 2009). The present results too suggest that the prevailing conditions under the bamboo canopy favour the establishment of light-loving forest species such as $P$. suberifolium, $C$. baccifera and $S$. asper than typical shade-loving forest species. Moreover, bamboos and lianas, being excellent competitors, reduce the available resources for tree seedlings to establish and thrive, further adversely influencing the tree seedling emergence in bamboo forests (Tabarelli \& Mantovani 2000, Griscom and Ashton 2003, Schnitzer et al. 2005). Keeping in line with the species-specific microsite segregation theory (Wiegand et al. 2009), D. longan, one of the most common tree species in these native forests, showed a better survival in non-bamboo forests, while seedlings of $P$. suberifolium, an early successional species, showed higher prevalence in bamboo forests. Caccia et al. (2009) too noted species-specific patterns of seedling survival in forests dominated by bamboo. Forest species that cannot stand high desiccation stress are able to survive well under the canopy of nonbamboo forests, while sun-loving species perform better in disturbed forests where bamboo prevails, indicating the importance of microsite segregation even during the early stages of forest seedlings with varying abilities to withstand stresses (Wiegand et al. 2009).

The surface litter layer in the forest floor plays a crucial role influencing the seedling emergence and seed persistence by acting as a mechanical barrier for seedling emergence and altering the micro-environment in the forest floor through changes in soil temperature, moisture and light (Facelli and Pickett 1991, Holmgren et al 1997, Zhang et al. 2007). According to the present results, non-bamboo forests accumulate more surface litter (dry weights) in comparison to bamboo forests, and this difference was more marked during the wet season. Though the dry weights of the surface litter are high in $-\mathrm{Bb}$ forests (with a litter depth of approximately $5-15 \mathrm{~cm}$ ) mainly due to the greater presence of broadleaved species, the field observations noted a thicker surface litter layer in $+\mathrm{Bb}$ forests (approximately $10-40 \mathrm{~cm}$ in deep). In the current study, the lowest recruitment and survival of seedlings in $+\mathrm{Bb}$ were recorded during the month of July, possibly due to higher litter accumulation prompted by prevailing dry and windy weather conditions. Bamboos are known to produce substantial amounts of light-weighted leaf litter thus acting as a mechanical barrier for seedling emergence (Griscom \& Ashton 2003, Zhou et al. 2005, Larpkern 2011). This thick surface litter layer seems to impose an adverse influence on the germination of tree seedlings by obstructing seeds to touch the soil (Wang et al 2008, Ruprecht \& Szabo 2012, Donath \& Eckstein 2010).

Irrespective of the bamboo spread, the seedlings showed high seasonality with more recruits and survival during the wet season. However, tree and shrub seedlings consistently survived better in non-bamboo forests throughout all seasons, while the opposite was observed with herb and liana seedlings, providing further evidence for life-form driven preferences by seedlings. The overall results indicated that the regeneration potential of these native forests has been modified, possibly due to altered micro-environmental conditions in forests following the bamboo spread. The results also demonstrated the compositional differences of seedling communities among the two forest patches, suggesting the ability of the bamboo spread to alter the composition and structure of these native forests over time. However, the bamboo-driven impacts on the regeneration potential could vary depending on the degree of expansion, climate, topographical and anthropogenic factors. At present, the bamboo has expanded its territories in strict nature reserves (Ritigala and Minneriya-Giritale) and sanctuaries (Victoria-Randenigala-Rantambe) in Sri Lanka. Therefore, it is vital to conduct 
more comprehensive research to identify intrinsic factors and underlying mechanisms of these bamboo-driven detrimental influences on regeneration potentials of native forests in order to introduce measures to restore and protect these highly vulnerable ecosystems in the tropics.

\section{ACKNOWLEDGEMENTS}

The authors wish to thank the National Research Council, Sri Lanka (Grant No: 16054) and University of Peradeniya (Grant No: URG/2016/90/S) for providing financial support to conduct this study.

\section{REFERENCES}

Abe M, Izaki J, Miguchi H et al. 2002. The effects of Sasa and canopy gap formation on tree regeneration in an old beech forest. Vegetation Science13: 565.

Araujo LS. 2008. Padroes e condicionantes da dinamica da paisagemnafloresta com bambus do Parque Estadual Intervales, Sao Paulo, Brazil. PhD thesis, Excola Superior de Agrcultura Luiz de Queiroz, University of Sao Paulo, Sao Paulo.

Benzhi Z, Maoui F, Jinzong X, Xiaosheng Y \& Zhengcai L. 2005. Ecological functions of bamboo forest: research and application. Journal of Forest Research 16: 143-147. doi: 10.1007/BF02857909.

Bhadouria R, Singh R, Srivastava P \& Raghubanshi As. 2016. Understanding the ecology of tree-seedling growth in dry tropical environment: a management perspective. Energy Ecology and Environment 1: 296-309.

Caccia FD, Chaneton EJ \& Kitzberger T. 2009. Direct and indirect effects of understorey bamboo shape tree regeneration niches in a mixed temperate forest. Oecologia 161: 771-780.

Campanello PI, Gatti MG, Ares A, Monti L. \&Goldstein G. 2007. Tree regeneration and microclimate in a liana and bamboo-dominated semideciduous Atlantic forest. Forest Ecology and Management 252: 108-117.

CinTra R. 1997. Leaf litter effects on seed and seedling predation of the palm Astrocaryum murumuru and the legume tree Dipterix micrantha in Amazonian. Tropical Ecology 13: 709-725. doi.org/10.1017/ S0266467400010889.

CoOmes DA \& GRUBB PJ. 2000. Impacts of root competition on forests and woodlands: a theoretical framework and review of experiments. Ecological Monographs 70: 171-172.

Donath TW \& Eckstein RL. 2010. Effects of bryophytes and grass litter on seedling emergence vary by vertical seed position and seed size. Plant Ecology 207: 257-268. http://dx.doi.org/10.1007/ s11258-009-9670-8.
FACELli JM \& Pickett STA. 1991. Plant litter: its dynamics and effects on plant community structure. Botanical Reviews 57: 1-32.

FANTINI AC \& GuRIEs RP. 2007. Forest structure and productivity of palmiteiro (Euterpe edulis martius) in the Brazilian Mata Atlantica. Forest Ecology and Management 242: 185-194. doi.org/10.1016/ j.foreco.2007.01.005.

FARAH FT, RODRIGUES RR \& SANTOS FAM 2014. Forest destructuring as revealed by the temporal dynamics of fundamental species-case study of Santa Genebra Forest in Brazil. Ecological Indicators 37: 40-44. doi:10.1016/ j.ecolind.2013.09.01139.

Felker RM, Rovedder APM, LONGHi SJ, Araújo EF, Stefanello MDM \& Peccatti A. 2017. Impact of Bambusa tuldoides Munro (Poaceae) on forest regeneration. Cerne 23: 275-282. doi: 10.1590/01047760201723022297.

GAGNON PR \& PlatT WJ. 2008. Reproductive and seedling ecology of a semelparous native bamboo (Arundinaria gigantea, Poaceae). Journal of the Torrey Botanical Society 135: 309-316.

GERHARDT K 1996. Effects of root competition and canopy openness on survival and growth of tree seedlings in a tropical seasonal dry forest. Forest Ecology and Management 92: 33-48.

Griscom MBW \& Ashton MS. 2003. Bamboo control of forest succession: Guadua sarcocarpa in Southeastern Peru. Forest Ecology and Management 175: 445-454.

Grombone-Guaratini M, Alves LF \& Vinha D. 2014. Seed rain in areas with and without bamboo dominance within an urban fragment of the Atlantic Forest. Acta Botanica Brasilica 28: 76-85. doi: 10.1590/ S0102-33062014000100008.

Guilherme FAG, Oliveira-Filho AT, Appolinário V \& BEARZOTI E. 2004. Effects of flooding regime and woody bamboos on tree community dynamics in a section of tropical semideciduous forest in South-Eastern Brazil. Plant Ecology 174: 19-36. doi:10.1023/B:VEGE.0000046051.97752.cd.

Gunatilleke N, Pethiyagoda R \& Gunatilleke S. 2008. Biodiversity of Sri Lanka. National Science Foundation Sri Lanka 36: 25-62.

Holmgren M, Scheffer M \& Huston MA. 1997. The interplay of facilitation and competition in plant communities. Ecology 78: 1966-1975. doi: $10.2307 / 2265937$

Kercher SM \& Zedler JB. 2004. Multiple disturbances accelerate invasion of reed canary grass (Phalaris arundinacea L.) in a mesocosm study. Oecologia 138: 455-464.

Kostel-Hughes F, Young TP \& WeHR JD. 2005. Effects of leaf litter depth on the emergence and seedling growth of deciduous forest tree species in relation to seed size. The Torrey Botanical Society 132: 50-61.

Larpkern P, Moe SR \& Totland O. 2011. Bamboo dominance reduces tree regeneration in a disturbed tropical forest. Oecologia 165: 161-168. doi.org/10.1007/s00442-010-1707-0.

Lima RAF, Rother DC, Muler AE, Lepsch IF \& Rodrigues RR. 2012. Bamboo overabundance alters forest 
structure and dynamics in the Atlantic Forest hotspot. Biological Conservation 147: 32-39. doi. org/10.1016/j.biocon.2012.01.015.

LiU W, Fox JED \& XU Z. 2000. Leaf litter decomposition of canopy trees, bamboo and moss in a montane moist evergreen broad-leaved forest on Ailao Mountain, Yunnan, south-west China. Ecological Research 15: 435-447. doi.org/10.1046/j.14401703.2000.00366.x.

MaLik ZA \& BhatT AB. 2016. Regeneration status of tree species and survival of their seedlings in Kedarnath Wildlife Sanctuary and its adjoining areas in Western Himalaya, India. Tropical Ecology 57: 677-690.

Muler A, Rother DC, Brancalion PHS, Naves RP, Rodrigues RR \& Pizo MA. 2014. Can overharvesting of a non-timber-forest product change the regeneration dynamics of a tropical rainforest? The case study of Euterpe edulis. Forest Ecology and Management 324: 117-125. doi:10.1016/j.foreco.2013.09.001.

Murphy PG \& Lugo AE. 1986. Ecology of Tropical Dry Forest. Annual Review of Ecology and Systematics17: 67-88. doi.org/10.1146/annurev. es.17.110186.000435.

Narukawa Y \& Yamamoto S. 2002. Effects of dwarf bamboo (Sasa sp.) and forest floor microsites on conifer seedling recruitment in a subalpine forest, Japan. Forest Ecology and Management 163: 61-70.

Paul JR, Randle AM, Chapman CA \& Chapman LJ. 2004. Arrested succession in logging growth and survival limiting? African Journal of Ecology 42: 245-251. doi. org/10.1111/j.1365-2028.2004.00435.x.

Rother DC, Jordano P, Rodrigues RR \& Pizo MA. 2013. Demographic bottlenecks in tropical plant regeneration: a comparative analysis of causal influences. Perspectives in Plant Biology, Systematics and Evolution 15: 86-96. doi:10.1016/j. ppees.2012.12.004.

Rother DC, Rodrigues RR \& Pizo MA. 2016. Bamboo tickets alter the structure of Euterpe edulis population: A threatened palm of the Atlantic forest. Acta Oecologica 70: 96-102. doi:10.1016/j. actao.2015.11.008.

Rother DC, Rodrigues RR \& Pizo MA. 2009. Effects of bamboo stands on seed rain and seed limitation in a rainforest. Forest Ecology and Management 257: 885-892. https://doi.org/10.1016/j. foreco.2008.10.022

Ruprecht E \& SzABo A. 2012. Grass litter is a natural seed trap in long-term undisturbed grassland. Vegetation Science 23: 495-504. doi: 10.1111/j.16541103.2011.01376.x.

Santos SLD \& VAlio IFM. 2002. Litter accumulation and its effect on seedling recruitment in a Southeast Brazilian Tropical Forest. Brazilian Journal of Botany 25: 89-92.

Sarojam N \& Kumar MSM. 2001. Bambusa bambos (L.) Voss, KFRI Consultancy Report 1 (Part 1). Kerala Forest Research Institute, Kerala.

Schnitzer SA, Dalling JW \& Carson WP. 2000. The impact of lianas on tree regeneration in tropical forest canopy gaps: evidence for an alternative pathway of gap-phase regeneration. Ecology 88: 655-666.

Schnitzer SA, Kuzee ME \& Bongers F. 2005. Disentangling above- and below-ground competition between lianas and trees in a tropical forest. Ecology 93: 1115-1125. https://doi.org/10.1111/j.13652745.2005.01056.x.

Somasekeram T, Perera lag, Perera MP, De Silva BG, Karunanayake MM \& Epitawatta DS. 1988. National Atlas. Survey Department of Sri Lanka, Colombo.

Tabarelli M \& Mantovani W. 2000. Gap-phase regeneration in a tropical montane forest: the effects of gap structure and bamboo species. Plant and Ecology 148: 149-155.

TANAKa N. 1988. Tree invasion into patchy dwarf-bamboo thickets within a climax beech-fir forest in Japan. Pp 253-260 in During JJ et al. (eds). Diversity and Pattern in Plant Communities. Academic Publishing, The Hague, Netherlands.

Taylor AH, Jinyan H \& Shigiang Z 2004. Canopy tree development and undergrowth bamboo dynamics in old-growth Abies-Betula forests in southwestern China: a 12 year study. Forest Ecology and Management 200: 347-360.

Taylor AH, Jang SW, Zhao LJ, Liang CP, Miao CJ \& HuANG JY. 2006. Regeneration patterns and tree species coexistence in old-growth Abies-Picea forests in southwestern China. Forest Ecology and Management 223: 303-317.

TAYLOR AH \& Zisheng Q. 1988. Regeneration patterns in old growth Abies-Betula forests in the Wolong natural reserve, Sichuan, China. Ecology 76: 1204-1218.

VADIGI S \& WARD D. 2013. Shade, nutrients, and grass competition are important for tree sapling establishment in a humid savanna. Ecosphere 4: 142.

WANG B, WeI WJ, XING ZK, LI SN \& BAI XL. 2008. Carbon storage of bamboo forest ecosystem in China. Ecology and Environment 17: 1680-1684.

WANG YJ, SHI XP \& TAO JP. 2012. Effects of different bamboo densities on understory species diversity and trees regeneration in an Abies faxoniana forest, southwest China. Scientific Research and Essays 7: 660-668.

Wiegand T, Huth A \& Martinez I. 2009. Recruitment in tropical tree species: revealing complex spatial patterns. American Naturalist 174: 106-140.

Wijewickrama MPT, Karunaratne WAIP, Wijesundara DSA \& Madawala HMSP. 2019. Bambusa bambos (L.) Voss alters regeneration potential in Tropical Moist Evergreen Forests in Sri Lanka. Pp115 in Proceedings of ATBC-Asia Pacific Conference 2019. 10-13 September 2019, Sri Lanka.

WiJEWickrama MPT, KarunaratNe WAIP, WiJESUNDARA DSA \& Madawala HMSP. 2020. Bambusa bambos (L.) Voss. alters structure and composition of native forests: a study from moist evergreen forests in Sri Lanka. Ceylon Journal of Science 49: 173-184.

Yeasmin L, Ali MN, Gantait S \& Chakraborty S. 2015. Bamboo: an overview of its genetic diversity and characterization. Biotechnology 5: 1-11. doi: 10.1007/ s13205-014-0201-5. 
ZhANG R, HU X, BASKIN JM ET AL. 2017. Effects of litter on seedling emergence and seed persistence of three common species on the Loess Plateau in Northwestern China. Frontiers in Plant Science 8: 103. doi: $10.3389 /$ fpls.2017.00103.
Zhou B, Fu M, Xie J, Xie JZ, Yang XS \& Li ZC. 2005. Ecological functions of bamboo forest: research and application. Forest Research 16: 143-147. doi: 1007-662X(2005)02-0143-05. 
Appendix Plant species recorded in upper vegetation layer (above $2 \mathrm{~m}$ in height) in bamboo $(+\mathrm{Bb})$ and non-bamboo (-Bb) forests in Moragahakanda, Sri Lanka.

\begin{tabular}{|c|c|c|c|c|c|}
\hline Family & Species & Origin & Life form & $+\mathrm{Bb}$ & $-\mathrm{Bb}$ \\
\hline Acanthaceae & Blepharis maderaspatensis & $\mathrm{N}$ & $\mathrm{H}$ & $t$ & \\
\hline Acanthaceae & Lepidagathis fasciculata & $\mathrm{N}$ & $\mathrm{H}$ & t & \\
\hline Acanthaceae & Elytraria acaulis & $\mathrm{N}$ & $\mathrm{H}$ & t & \\
\hline Acanthaceae & Rhinacanthus polonnaruwensis & $\mathrm{E}$ & $\mathrm{H}$ & t & \\
\hline Achariaceae & Hydnocarpus venenata & $\mathrm{E}$ & $\mathrm{T}$ & & t \\
\hline Anacardiaceae & Nothopegia beddomei & $\mathrm{N}$ & $\mathrm{T}$ & & t \\
\hline Anacardiaceae & Mangifera zeylanica & $\mathrm{E}$ & $\mathrm{T}$ & & t \\
\hline Annonaceae & Alphonsea sclerocarpa & $\mathrm{N}$ & $\mathrm{T}$ & & t \\
\hline Annonaceae & Miliusa indica & $\mathrm{N}$ & $\mathrm{S}$ & t & t \\
\hline Annonaceae & Polyalthia coffeoides & $\mathrm{N}$ & $\mathrm{T}$ & & t \\
\hline Annonaceae & Polyalthia korinti & $\mathrm{N}$ & $\mathrm{S}$ & t & t \\
\hline Annonaceae & Uvaria sphenocarpa & $\mathrm{E}$ & $\mathrm{L}$ & t & t \\
\hline Apocynaceae & Carissa spinarum & $\mathrm{N}$ & $\mathrm{L}$ & t & t \\
\hline Apocynaceae & Ichnocarpus frutescens & $\mathrm{N}$ & $\mathrm{L}$ & t & $t$ \\
\hline Apocynaceae & Aganosma cymosa & $\mathrm{N}$ & $\mathrm{L}$ & t & t \\
\hline Apocynaceae & Hemidesmus indicus & $\mathrm{N}$ & $\mathrm{L}$ & t & \\
\hline Araceae & Amorphophallus sylvaticus & $\mathrm{N}$ & $\mathrm{H}$ & t & \\
\hline Arecaceae & Caryota urens & $\mathrm{N}$ & $\mathrm{T}$ & & t \\
\hline Asteraceae & Elephantopus scaber & $\mathrm{N}$ & $\mathrm{H}$ & t & \\
\hline Asteraceae & Chromolaena odorata & Ex & $\mathrm{S}$ & t & \\
\hline Asteraceae & Mikania cordata & Ex & $\mathrm{L}$ & t & \\
\hline Asteraceae & Vernonia cinerea & $\mathrm{N}$ & $\mathrm{H}$ & t & \\
\hline Bignoniaceae & Stereospermum colais & $\mathrm{N}$ & $\mathrm{T}$ & t & \\
\hline Boraginaceae & Carmona retusa & $\mathrm{N}$ & $\mathrm{S}$ & t & \\
\hline Burseraceae & Commiphora caudata & $\mathrm{N}$ & $\mathrm{T}$ & t & t \\
\hline Cannabaceae & Celtis philippensis & $\mathrm{N}$ & $\mathrm{T}$ & t & \\
\hline Capparaceae & Capparis brevispina & $\mathrm{N}$ & S & $t$ & t \\
\hline Capparaceae & Capparis rotundifolia & $\mathrm{N}$ & $\mathrm{L}$ & & $t$ \\
\hline Celastraceae & Salacia oblonga & $\mathrm{N}$ & $\mathrm{L}$ & t & $t$ \\
\hline Commelinaceae & Commelina benghalensis & $\mathrm{N}$ & $\mathrm{H}$ & $t$ & \\
\hline Convolvulaceae & Ipomoea sp. & & $\mathrm{L}$ & t & \\
\hline Cornaceae & Alangium salviifolium & $\mathrm{N}$ & $\mathrm{L}$ & t & t \\
\hline Cucurbitaceae & Momordica charantia & $\mathrm{N}$ & $\mathrm{L}$ & t & \\
\hline Cycadaceae & Cycas nathorstii & $\mathrm{N}$ & $\mathrm{T}$ & t & \\
\hline Dioscoreaceae & Dioscorea pentaphylla & $\mathrm{N}$ & $\mathrm{L}$ & t & $t$ \\
\hline Ebenaceae & Diospyros ebenoides & $\mathrm{E}$ & $\mathrm{T}$ & t & $t$ \\
\hline Ebenaceae & Diospyros ebenum & $\mathrm{N}$ & $\mathrm{T}$ & & t \\
\hline Ebenaceae & Diospyros ovalifolia & $\mathrm{N}$ & $\mathrm{T}$ & & $t$ \\
\hline Ebenaceae & Diospyros vera & $\mathrm{N}$ & S & t & $t$ \\
\hline Erythroxylaceae & Erythroxylum zeylanicum & $\mathrm{E}$ & $S$ & $t$ & t \\
\hline Euphorbiaceae & Croton laccifer & $\mathrm{N}$ & $S$ & t & \\
\hline Euphorbiaceae & Croton officinalis & $\mathrm{N}$ & $\mathrm{L}$ & $t$ & \\
\hline Euphorbiaceae & Dimorphocalyx glabellus & $\mathrm{N}$ & $\mathrm{T}$ & t & $t$ \\
\hline Euphorbiaceae & Macaranga peltata & $\mathrm{N}$ & $\mathrm{T}$ & t & \\
\hline
\end{tabular}




\begin{tabular}{|c|c|c|c|c|c|}
\hline Euphorbiaceae & Mallotus philippensis & $\mathrm{N}$ & $\mathrm{T}$ & $t$ & t \\
\hline Euphorbiaceae & Mallotus resinosus & $\mathrm{E}$ & $\mathrm{T}$ & & t \\
\hline Euphorbiaceae & Sapium insigne & $\mathrm{N}$ & $\mathrm{T}$ & t & \\
\hline Euphorbiaceae & Tragia hispida & $\mathrm{N}$ & $\mathrm{L}$ & $t$ & t \\
\hline Fabaceae & Abrus precatorius & $\mathrm{N}$ & $\mathrm{L}$ & t & \\
\hline Fabaceae & Acacia caesia & $\mathrm{N}$ & $\mathrm{L}$ & t & t \\
\hline Fabaceae & Albizia lebbeck & $\mathrm{N}$ & $\mathrm{T}$ & & t \\
\hline Fabaceae & Bauhinia racemosa & $\mathrm{N}$ & $\mathrm{T}$ & t & \\
\hline Fabaceae & Derris parviflora & $\mathrm{E}$ & $\mathrm{L}$ & t & t \\
\hline Fabaceae & Unidentified herb sp. & & $\mathrm{H}$ & t & \\
\hline Fabaceae & Desmodium pryonii & $\mathrm{N}$ & $\mathrm{H}$ & t & $t$ \\
\hline Fabaceae & Ormocarpum sennoides & $\mathrm{N}$ & $\mathrm{S}$ & t & \\
\hline Fabaceae & Tephrosia purpurea & $\mathrm{N}$ & S & t & \\
\hline Hernandiaceae & Gyrocarpus americanus & $\mathrm{N}$ & $\mathrm{T}$ & t & t \\
\hline Hypoxidaceae & Curculigo orchioides & $\mathrm{N}$ & $\mathrm{H}$ & t & t \\
\hline Lamiaceae & Premna tomentosa & $\mathrm{N}$ & $\mathrm{T}$ & t & \\
\hline Lamiaceae & Leucas zeylanica & $\mathrm{N}$ & $\mathrm{H}$ & t & \\
\hline Lamiaceae & Vitex altissima & $\mathrm{N}$ & $\mathrm{T}$ & t & t \\
\hline Lauraceae & Alseodaphne semecarpifolia & $\mathrm{N}$ & $\mathrm{T}$ & t & \\
\hline Lauraceae & Neolitsea cassia & $\mathrm{N}$ & $\mathrm{T}$ & t & t \\
\hline Loganiaceae & Strychnos minor & $\mathrm{N}$ & $\mathrm{L}$ & t & $t$ \\
\hline Loganiaceae & Strychnos nux-vomica & $\mathrm{N}$ & $\mathrm{T}$ & t & \\
\hline Malpighiaceae & Hiptage benghalensis & $\mathrm{N}$ & $\mathrm{L}$ & t & \\
\hline Malvaceae & Hibiscus micranthus & $\mathrm{N}$ & $\mathrm{H}$ & t & \\
\hline Malvaceae & Helicteres isora & $\mathrm{N}$ & $\mathrm{S}$ & t & \\
\hline Malvaceae & Pterospermum suberifolium & $\mathrm{N}$ & $\mathrm{T}$ & t & t \\
\hline Malvaceae & Berrya cordifolia & $\mathrm{N}$ & $\mathrm{T}$ & t & \\
\hline Malvaceae & Grewia damine & $\mathrm{N}$ & $\mathrm{T}$ & t & \\
\hline Malvaceae & Grewia helicterifolia & $\mathrm{N}$ & $\mathrm{T}$ & t & t \\
\hline Malvaceae & Grewia orientalis & $\mathrm{N}$ & $\mathrm{L}$ & t & \\
\hline Malvaceae & Sida sp. & $\mathrm{N}$ & $\mathrm{H}$ & t & \\
\hline Meliaceae & Chukrasia tabularis & $\mathrm{N}$ & $\mathrm{T}$ & t & $t$ \\
\hline Meliaceae & Cipadessa baccifera & $\mathrm{N}$ & $\mathrm{S}$ & t & t \\
\hline Meliaceae & Munronia pinnata & $\mathrm{N}$ & $\mathrm{H}$ & t & \\
\hline Meliaceae & Walsura trifoliolata & $\mathrm{N}$ & $\mathrm{T}$ & & t \\
\hline Menispermaceae & Cissampelos pareira & $\mathrm{N}$ & $\mathrm{L}$ & t & \\
\hline Menispermaceae & Tinospora sinensis & $\mathrm{N}$ & $\mathrm{L}$ & t & \\
\hline Moraceae & Ficus sp. 1 & & $\mathrm{~T}$ & t & \\
\hline Moraceae & Ficus sp. 2 & & $\mathrm{~T}$ & & t \\
\hline Moraceae & Streblus asper & $\mathrm{N}$ & $\mathrm{T}$ & t & t \\
\hline Moraceae & Streblus taxoides & $\mathrm{N}$ & $\mathrm{T}$ & t & t \\
\hline Myrtaceae & Eugenia bracteata & $\mathrm{E}$ & $\mathrm{T}$ & t & $t$ \\
\hline Myrtaceae & Eugenia rotundata & $\mathrm{E}$ & $\mathrm{T}$ & & t \\
\hline Ochnaceae & Ochna lanceolata & $\mathrm{N}$ & $\mathrm{T}$ & t & t \\
\hline Oleaceae & Jasminum angustifolium & $\mathrm{N}$ & $\mathrm{L}$ & t & \\
\hline Oxalidaceae & Biophytum sensitivum & $\mathrm{N}$ & $\mathrm{H}$ & t & \\
\hline Phyllanthaceae & Phyllanthus polyphyllus & $\mathrm{N}$ & $\mathrm{S}$ & t & \\
\hline
\end{tabular}




\begin{tabular}{|c|c|c|c|c|c|}
\hline Phyllanthaceae & Sauropus rigidus & $\mathrm{E}$ & $\mathrm{H}$ & $t$ & \\
\hline Phyllanthaceae & Cleistanthus patulus & $\mathrm{N}$ & $\mathrm{T}$ & & $t$ \\
\hline Phyllanthaceae & Flueggea leucopyrus & $\mathrm{N}$ & $\mathrm{S}$ & $t$ & \\
\hline Phyllanthaceae & Phyllanthus amarus & $\mathrm{N}$ & $\mathrm{H}$ & $t$ & \\
\hline Piperaceae & Peperomia pellucida & Ex & $\mathrm{H}$ & $t$ & \\
\hline Piperaceae & Piper sylvestre & $\mathrm{N}$ & $\mathrm{L}$ & + & + \\
\hline Poaceae & Bambusa bambos & $\mathrm{N}$ & $\mathrm{T}$ & $t$ & \\
\hline Poaceae & Grass sp. 1 & & G & $t$ & + \\
\hline Poaceae & Grass sp. 2 & & G & + & + \\
\hline Pteridaceae & Adiantum sp. & & $\mathrm{F}$ & $t$ & t \\
\hline Pteridaceae & Hemionitis arifolia & $\mathrm{N}$ & $\mathrm{F}$ & $t$ & $t$ \\
\hline Putranjiavaceae & Drypetes sepiaria & $\mathrm{N}$ & $\mathrm{T}$ & $t$ & + \\
\hline Rhamnaceae & Ventilago madraspatana & $\mathrm{N}$ & $\mathrm{L}$ & + & + \\
\hline Rhamnaceae & Ziziphus oenopolia & $\mathrm{N}$ & $\mathrm{L}$ & $t$ & + \\
\hline Rhizophoraceae & Cassipourea ceylanica & $\mathrm{N}$ & $\mathrm{T}$ & $t$ & $t$ \\
\hline Rubiaceae & Canthium coromandelicum & $\mathrm{N}$ & $\mathrm{T}$ & + & + \\
\hline Rubiaceae & Ixora coccinea & $\mathrm{N}$ & $\mathrm{T}$ & $t$ & + \\
\hline Rubiaceae & Ixora pavetta & $\mathrm{N}$ & $\mathrm{T}$ & $t$ & \\
\hline Rubiaceae & Psilanthus wightianus & $\mathrm{N}$ & $\mathrm{S}$ & $t$ & \\
\hline Rubiaceae & Tarenna asiatica & $\mathrm{N}$ & $\mathrm{T}$ & $t$ & \\
\hline Rubiaceae & Spermacoce sp. & $\mathrm{N}$ & $\mathrm{H}$ & $t$ & \\
\hline Rutaceae & Atalantia ceylanica & $\mathrm{N}$ & $\mathrm{S}$ & $t$ & + \\
\hline Rutaceae & Chloroxylon swietenia & $\mathrm{N}$ & $\mathrm{T}$ & $t$ & + \\
\hline Rutaceae & Glycosmis pentaphylla & $\mathrm{N}$ & $\mathrm{S}$ & $t$ & + \\
\hline Rutaceae & Micromelum minutum & $\mathrm{E}$ & $\mathrm{T}$ & & t \\
\hline Rutaceae & Murraya paniculata & $\mathrm{N}$ & $\mathrm{T}$ & $t$ & + \\
\hline Rutaceae & Pleiospermium alatum & $\mathrm{N}$ & $\mathrm{T}$ & $t$ & + \\
\hline Rutaceae & Toddalia asiatica & $\mathrm{N}$ & $\mathrm{L}$ & $t$ & \\
\hline Salicaceae & Flacourtia indica & $\mathrm{N}$ & $\mathrm{T}$ & $t$ & \\
\hline Sapindaceae & Allophylus cobbe & $\mathrm{N}$ & $\mathrm{L}$ & $t$ & + \\
\hline Sapindaceae & Dimocarpus longan & $\mathrm{N}$ & $\mathrm{T}$ & + & + \\
\hline Sapindaceae & Lepisanthes senegalensis & $\mathrm{N}$ & $\mathrm{T}$ & & + \\
\hline Sapindaceae & Lepisanthes tetraphylla & $\mathrm{N}$ & $\mathrm{T}$ & $t$ & $t$ \\
\hline Sapindaceae & Sapindus emarginatus & $\mathrm{N}$ & $\mathrm{T}$ & $t$ & \\
\hline Sapindaceae & Schleichera oleosa & $\mathrm{N}$ & $\mathrm{T}$ & + & + \\
\hline Urticaceae & Laportea interrupta & $\mathrm{N}$ & $\mathrm{H}$ & $t$ & \\
\hline Verbenaceae & Lantana camara & Ex & $\mathrm{S}$ & $t$ & \\
\hline Vitaceae & Cayratia pedata & $\mathrm{N}$ & $\mathrm{H}$ & $t$ & + \\
\hline Vitaceae & Cissus heyneana & $\mathrm{N}$ & $\mathrm{L}$ & + & \\
\hline Vitaceae & Leea indica & $\mathrm{N}$ & $\mathrm{S}$ & $t$ & \\
\hline Zingiberaceae & Zingiber wightianum & $\mathrm{N}$ & $\mathrm{H}$ & $t$ & t \\
\hline
\end{tabular}

T: tree, S: shrub, L: liana, H: herb, G: grass, F: fern, E: endemic, N: native, Ex: exotic; Nomenclature follows The Plant List (2013) 